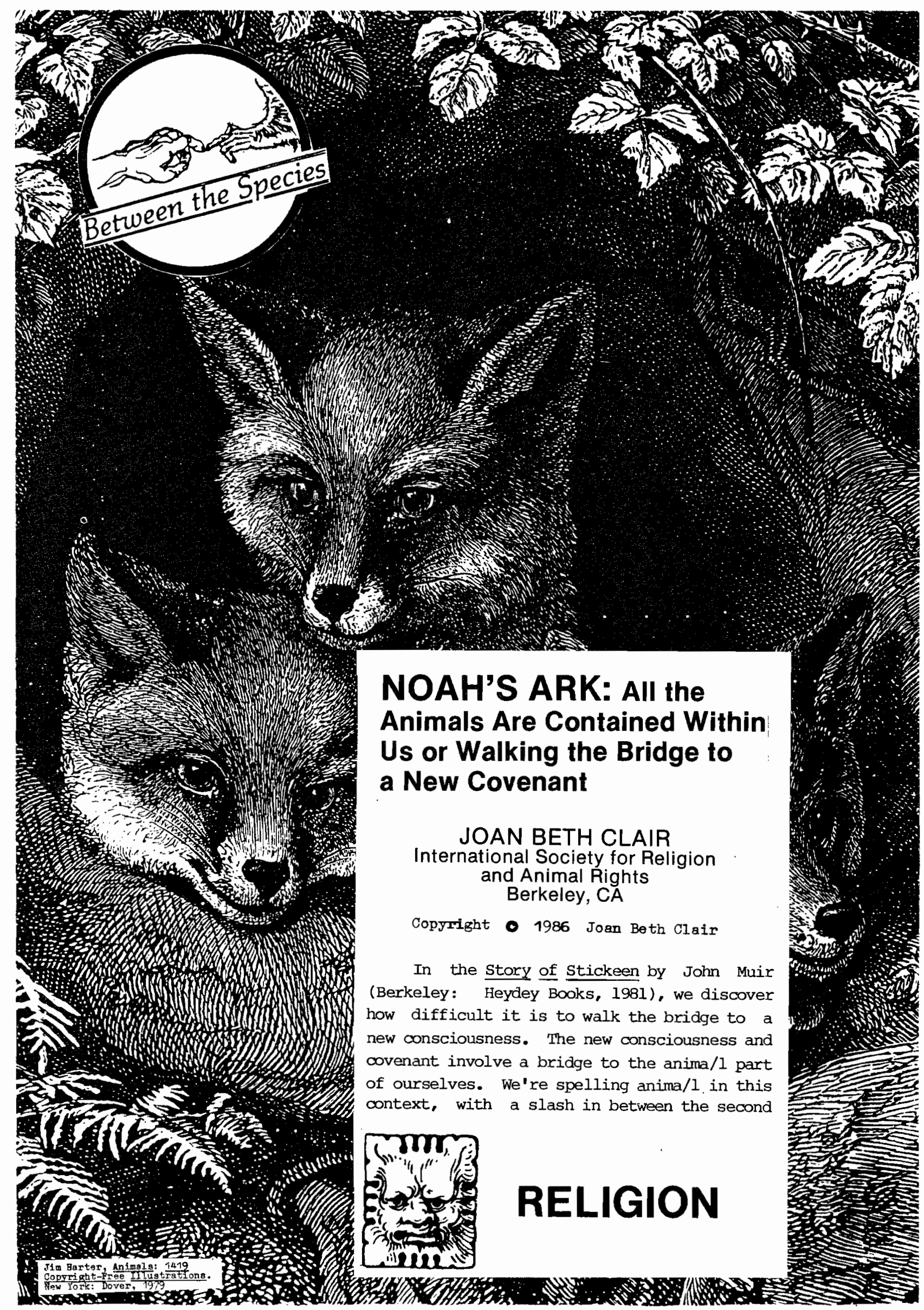


"a" and the letter " 1 " to point out that the word animal is derived from anima, a word for soul. We're all "walking around souls," or "nephesh," an Old Testament, Hebrew word for soul. All of the different forms of life in Genesis were described as souls. The new consciousness and covenant involve knowing that all anima/ls are one Anima/l or Anima principle. In the new covenant, unlike the aftermath of Noah's ark, 'some anima/ls will not have to live in terror of human anima/ls, because we will no longer fear one part of ourselves. We will no longer be projecting our shadow on other anima/ls.

How difficult it is to walk a bridge to a new consciousness. We will be laughed at along the way. Anima/ls are supposed to be beneath us. We are supposed to be above them. Yet, in the story of Noah, the ani$\mathrm{ma} / \mathrm{ls}$ walk side by side into the ark. In the ark we are all one. In the ark are all of us, contained in God.

But let us tell the story of stickeen. Stickeen is a little dog who attaches himself to John Muir in one of his expeditions. Muir has joined his friend the Reverend $S$. H. Young to explore "the icy region of southeastern Alaska." Muir urges Young to leave Stickeen home saying, "This trip is not likely to be good for toy-dogs." Yet Stickeen attaches himself to Muir as if his life depends on it and follows Muir one morning on his trip up the glacier, though Muir tries to convince him to return home. Climbing the glacier together, Muir and Stickeen face one of the most difficult tasks of their lives. Facing the widest cravasse Muir says he has ever seen, there is only a narrow sliverbridge which can be used to cross it. With an impending storm at their backs, their only choice is to press on over the bridge, below which lies an unspeakable abyss.

Muir, overcoming his own fear, is suddenly confronted with Stickeen's fear which makes him forget, for a moment, that stickeen is a "dog." He begins to comfort him, unconsciously, as if Stickeen were a "frightened boy." He lets him know that it's necessary to walk over the sliver-bridge and that, in his own words, "No right way is easy in this rough world. We must risk our lives to save them." When Muir manages to cross to the other side, Stickeen, who seems to know exactly what is going on and what a terrible risk is being demanded of him, reveals even more fear than before. Muir, in a severe tone of voice, shouts to him that if he doesn't come over he will have to leave him and that he will probably be killed by wolves. "He knew very well what I meant," said Muir and finally, with the courage born of desperation, Stickeen successfully crosses the sliver-bridge, going "from the depths of despair to exultant, triumphant, unoontrollable joy." According to Muir, "Such passionate emotion was enough to kill him. Moses' stately song of triumph after escaping the Egyptians and the Red Sea was nothing to it. Neither of us feared another trial like this. Heaven would surely count one enough for a lifetime. The ice ahead was gashed by thousands of crevasses, but they were common ones. The joy of deliverance burned in us like fire, and we ran without fatigue, every muscle with immense rebound glorying in its strength."

However, Muir and Stickeen have not just managed to save their lives. They have crossed over the bridge into a new consciousness and into a new covenant. As Muir puts it, "I have known many dogs, and many a story I could tell of their wisdom and devotion;" but to none do I owe so much as to Stickeen. At first the least promising and least known of my dog-friends, he suddenly became the best known of them all. our storm-battle for life brought him to light, and through him as through a window I have ever since been looking with deeper sympathy into all my fellow mortals." Elsewhere, Muir has written, "He enlarged my life, extended its boundaries. In all my wild walks seldom have I ever had a more definite and useful message to bring back. Stickeen was the herald of a new gospel."

This new gospel that Muir witnessed to is that we are all One, one Anima/l principle, One soul. According to one of Muir's biographers, the new gospel "proclaimed the fundamental unity and sanctity of all living things."

John Muir realized that they had been tested and that they won't have to go through this test again. Stickeen, by stick-ing to the human, John Muir, in a seemingly irrational way and with great devotion, has enabled Muir to reach a greater vision of God. Stickeen's mission has been achieved. Both human and anima/l become one, have been saved. 
Muir has spoken well when he says to Stickeen, "We must risk our lives to save them." The salvation, as Jesus said, is not of this world as we know it or imagine it to be. "To be saved, we all must cross the bridge to anima/l consciousness, to the reclaiming of the anima/l, the soul within ourselves, to the knowledge that we are all one.

One of the terrors of crossing the bridge is the fear of being considered a child, or childish, in one's concern for other forms of life, or a bit eccentric. We would rather stay in the Ark, saying that the vision of unity is a drearn and not to be practiced when the waters die down and the Ark lands on ground.

Yet Noah's Ark is really a vision of the Kingdam/Queendom as revealed in Isaiah 11:9, in which the lion and the lamb will lie down together. The anima/ls go into the Ark two by two, and they apparently coexist together peacefully in the Ark. We don't hear about the law of predation operating in the Ark, or the food chain. When the anima/ls emerge, they do so without having been eaten up by each other. With the knowledge that all is one, one part of ourselves cannot be used against another part of ourselves. One part of ourselves cannot be sacrificed to another part.

If one is afraid of being ridiculed or regarded as childish in one's love for other forms of life, then it is good to remember that it is a child who will bring the Kingdom/Queendom in, who will "lead them."

Muir became like a little child again, talking to Stickeen as if he understood, as if he was human and then, in the discovery, that stickeen did understand. His belief in that was childlike. Becoming a child again, Muir could become a leader to a new consciousness.

Today, we are gathered for the second annual memorial service of The International Society for Religion and Animal Rights for all unnamed and suffering anima/ls. It is interesting to note that in the literature on death and dying, there's no mention of memorial services for anima/ls. When I mentioned this memorial service for anima/ls to one person, he thought it was going to be a memorial service for children. And in one sense he was right. Only those who have become children again in the sense Jesus was talking about can appreciate it.

In fact, children's literature is the only place where the burial of anima/ls and memorial services for anima/ls are acknowledged. Jim's Dog Muffins, for example, is a story by Miriam Cohen in which a child undergoes a grieving process for his dog. The other children learn to respect his grief and eventually Jim comes out of it. Another book, When Violet Died, by Mildred Kantrowitz, tells the story of some children who bury their pet bird and hold a memorial service for her. The book Stray Dog, by Carol Beach York, tells a story about a child who nurses a sick dog back to health. When the dog dies, anyway, after a little while, the child learns to keep on loving, even though it's hard.

In some of the literature on death and dying, it is stated that it is good for children to have anima/ls because they learn what death is about early on in life. Psychologists have said that giving pets to children helps them learn to be considerate and kind. These qualities can later be transferred to people. Implicit in this way of thinking is the idea that anima/ls are objects to be used to develop better relationships with other humans. Nowhere are there stories of adults burying their anima/ls, at least in Western society, and having memorial services for them. In Western culture, adults are not supposed to take the death of an anima/l friend so seriously. That is for children alone.

It might be wise to ask, at this point, what we mean by adulthood. Much of adulthood, as it is practiced, is conformity to a set of values and mores to ensure physical survival. Jesus did not believe in this form of survival or adulthood at any price. In his own quest to become like a child again, he was ridiculed, isolated and finally crucified. We all experience a little of these as we take our own steps to become like children again. In the process we throw off some of the adult mores which would rationalize values that would never be held if survival, in the physical sense, did not seem to be the price. Not that there is no place for this kind of survival, nor is it unimportant. But Jesus urges us to take another step, to trust

$$
\text { - continued p. } 93 \text { - }
$$


with bittersweet roses at center stage.

"Third runner-up • . . ." pronounced a perspiring Teddy. Gail's eyes were now struck by the glint of a shiny steak knife nervously fingered by a man sitting next to the young girl. Gail saw in the man a total incarnation of the throat-cutter toiling with slicing boldness in the darkness of his kill.

" . Annette Sergesian!" Another contestant was swept up by the thrill on and offstage, plied with roses, and deposited center stage.

"Second Iunner-up . . ." The drum roll pounded in her ears, filling Gail's head with echoes of the steady banging, clanking of schackles and conveyor chugging their way through and around the huge, turmaltuous slaughterhouse.

"Carol Sue Bigelowe!" Kisses, flashbulbs popping, once more red bouquet to flank its fresh-picked kin.

"The first runner-up . . ." A woman sat on the other side of the man fingering the steak knife. She, like the rest of the audience, was hanging on the tense atmosphere of the banquet hall, waiting for the runner-up's name. Gail didn't look at the woman. She was staring at something on the woman's dinner plate. It was a long piece of fat that the woman had apparently trimened fron her roast beef. When Gail recognized what it was, her right heel almost began involuntarily to twitch, self-consciously trying to rid itself of an invisible piece of factory fat.

" . Cindy Swensen!" Hands clasped to pretty blonde head, all eyes smiling at beaming blonde face, but eyes gradually turning back to Teddy and eleven all-or-nothing contestants.

"And now, the Nebraska Beef queen for 1978 - . ." At the word "Beef," Gail saw nothing of the scraps and bits of meat left on the plates of the people at the front table. She saw only what was in her mind's eye, and it was like the pieces of a jigsaw puzzle fitting together for the first time, forming a vivid picture of mutilated, dangling bodies bouncing along before her eyes. The picture was so real that she could even smell the same smell of damp, singed flesh and warm blood. i - . Miss Gail Shreve!" Her feet began moving stiffly forward, but her stanach began to heave. She started throwing up. Violently. Her body doubled up, and she bent over, throwing up repeatedly on the floor of the stage. As sie did so, gradually going to her knees, Randy was running to the front and onto the stage.

Gail's last upsurge had passed by the time he reached her, knelt, and pulled her body to his. She, lying splattered with her own vomit, and he, holding a pathetic young queen, were suddenly enveloped by a tremendous, incongruous sense of freedom. Freedom from pomp, freedom from rhetoric, freedom from bullshit.

They were oblivious to the other people around who had gathered to assist or to those who stood gaping in shock.

They were like two people kissing on a football field, deaf to the crowd, and not feeling self-conscious of their own passion. They had the freedom to dream that the moment would last forever.

\section{The End}

and believe in is survival beyond death, in a lif? heyond what we describe as reality here. He also asks that we trust that we will be supported by our Creator as we affirm childlike values at the expense of worldly or socalled "adult ones." In fact, we will discover the Kingdom/queendam.

Were these promises that only pertained to the time of Jesus? Was the world any less populated by the "too wise" at the time Jesus lived? Was it any less difficult to discover God then than now? Was it easier to become a child?

May we have the courage that stickeen and John Muir had to walk whatever tightropelike bridges we need to walk to a new consciousness and a new covenant. May we take the risk of becoming like little children, enduring ridicule and claiming God's promises. May we overcome our fear that we can never bridge the gaps within ourselves and in the world and survive. May we be mature enough not to hold onto false notions of maturity.

Amen 